\title{
THE EFFECT OF SAVING ACCOUNT OWNERSHIP AND ACCESS TO FINANCIAL INSTITUTIONS ON HOUSEHOLD LOANS IN INDONESIA
}

\author{
Robby Maulana* and Chaikal Nuryakin** \\ *Economic Bureau, Regional Secretariat, Provincial Government of West Kalimantan, Indonesia. \\ Email : robby.maulana81@alumni.ui.ac.id \\ **Faculty of Economics and Business, University of Indonesia, Jakarta, Indonesia
}

\begin{abstract}
This study investigates whether saving account ownership and access to financial institutions influence household credit in Indonesia. Using a multinomial logit regression model and a sample of 294,426 households from the 2018 national socioeconomic survey and the village level data, we find that account ownership is essential in encouraging formal credit and reducing informal credit. Access to commercial banks, rural banks, and cooperatives can then improve formal credit without significantly reducing informal credit. Hence, the government needs to encourage bank account ownership and facilitate access to financial institutions in order to promote formal credit and reduce informal credit.
\end{abstract}

Keywords: Account ownership; Credit access; Financial inclusion; Financial institutions. JEL Classification : E510; G210; G510.

Article history:

Received : August 07, 2020

Revised : March 12, 2021

Accepted : March 25, 2021

Available Online: September 30, 2021

https://doi.org/10.21098/bemp.v24i3.1428 


\section{INTRODUCTION}

This study assesses the importance of the access to financial institutions and account ownership to improving household access to credit. Credit can be a suitable instrument in poverty alleviation. Easier access to credit and opportunities for savings correlate with poverty reduction, especially for people in rural areas (Burgess et al., 2005). Individuals can use credit to fund investment in productive assets and human capital, which can generate income, and these credit can also be used as a tool for smoothing consumption during a crisis (Diagne, 1999; Ergungor, 2010; Li et al., 2011). Nevertheless, formal financial services have failed to act as the primary credit source for the poor. Instead, the poor tend to rely on informal financial services (Sanjaya and Nursechafia, 2016). Informal loans are primarily generated by individuals, who lend money informally without administrative requirements, and sometimes do not require a collateral. The primary informal sources are friends and family (Demirguc-Kunt et al., 2018; Fungáčová and Weill, 2015). These may also include loan sharks.

It is also often the case that people who are likely to receive formal credit and have easier access to formal credit choose to borrow from informal lenders because of the ease and flexibility of informal loans (Li et al., 2011; Sanjaya and Nursechafia, 2016). However, in return, they charge higher interest rates to borrowers than traditional banks (Gitaharie et al., 2014). People who fail to access formal credit are forced to use informal loans, which have higher interest rates but are more accessible. In the end, the informal loans increase debt and trap most households in poverty (Li et al., 2011).

Inclusive financial policies aiming to increase account ownership and expand formal financial institutions' reach are carried out to provide better credit access to those in need. Lessons from the 2008 crisis suggest that unbanked members of the low to middle income communities, who did not have a saving account, suffered immensely with no saving or access to credit. At the 2010 G-20 Summit in Toronto, nine principles for innovative financial inclusion were formulated. ${ }^{1}$ With these principles, the international community began to pay more attention to increase financial inclusion. Governments in most developing countries have worked towards making universal access to financial services a priority, assisting international agencies' efforts, such as the World Bank, to achieve this goal by 2020 (Kochar, 2018). One of the innovations in financial inclusion is the establishment of bank agents or branchless banking. ${ }^{2}$

According to the Global Findex Database 2017, more than half of the world's poor did not have a bank account, with the figures suggesting that $59 \%$ of people in developing countries did not have a savings account. The low ownership of accounts in formal financial institutions makes it difficult for people to access loans to fund venture capital and other investments, such as education or housing (Demirguc-Kunt et al., 2018; Hogarth and O'Donnell, 1999), whereas account

1 The principles aim to help create innovative financial inclusion policies. The nine principles for innovative financial inclusion consist of leadership, diversity, innovation, protection, empowerment, cooperation, knowledge, proportionality, and framework (G20 Financial Inclusion Expert Group, 2010).

2 Branchless banking in Indonesia, namely Laku Pandai (Branchless Banking Service for Financial Inclusion) and LKD (Digital Financial Services) (Nuryakin et al., 2017) 
ownership and financial institutions' existence provide greater access to the public to make payment transactions, save money, insure, and received loans (Allen et al., 2016; Demirgüç-Kunt and Klapper, 2013; Fitzpatrick, 2013).

Current research is inconclusive about the relationship between account ownership and credit. Some studies suggest that account ownership can encourage formal credit (Demirgüç-Kunt and Klapper, 2013; Fitzpatrick, 2013; Hogarth and O'Donnell, 1999). However, another reveals the outcome, where the existence of formal finance does not necessarily increase formal credit, but decreases informal credit (Diagne, 1999; Fungáčová and Weill, 2015; Giné, 2011; Mohieldin and Wright, 2000). Besides, there are also several different viewpoints regarding financial institutions and access to formal credit (Beck et al., 2007; Brown et al., 2016; Burgess et al., 2005; Carletti et al., 2018; Kumar et al., 2019).

Account ownership is referred to be the key to broader access to financial services, although most studies, if not all, focus more on demographic characteristics to financial inclusion (Akudugu, 2013; Allen et al., 2016; Ghosh and Vinod, 2017; Honohan, 2008; Li et al., 2011; Swamy, 2014; Van Rooyen et al., 2012). Only a few studies analyze the relationship between account ownership and credit. Previous research also show that reducing barriers to formal financial institutions has a vital role in improving financial services. Therefore, financial institutions' broad reach can reduce these barriers (Demirguc-Kunt et al., 2018; Ergungor, 2010; Esquivias et al., 2020).

This study contributes to the literature on financial inclusion from the perspective of household credit. Specifically, we examine whether account ownership and access to financial institutions have improved formal (and informal) credit in Indonesia. According to the World Bank (2018), Indonesia has the largest unbanked population (95 million people). While for loans, 32\% of adults in Indonesia borrow through friends or family, 16.1\% borrow through informal saving clubs, and loans through formal institutions amounted to $18.7 \%$. By 2019, the government was targeting to improve financial inclusion in Indonesia to $75.0 \%$. This financial inclusion target encouraged better access to financial services, with the primary objective being to encourage economic growth, poverty alleviation, reducing inequalities between individuals and among regions. ${ }^{3}$ This target has still not been achieved. Based on the latest survey released by Dewan Nasional Keuangan Inklusif (2019), account ownership only reached 55.7\%; in other words, just over $55 \%$ of the population have a saving account.

This study employs the 2018 national socioeconomic survey (Susenas) and the village potential (Podes) data released by Badan Pusat Statistik (BPS) to examine the link between access to credit and account ownership and access to finanical institutitons. Foreshadowing the main findings, our the multinomial logit regression results show a negative correlation between account ownership and informal credit and a positive correlation between account ownership and access to formal financial institutions' credit.

The remaining paper is structured as follows. Section II presents the literature, while Section III presents the data. Section IV explains the results and Section V provides some concluding remarks.

3 The 2016 Presidential Regulation of the Republic of Indonesia concerning the National Inclusive Finance Strategy contains the main target of financial inclusion. 


\section{LITERATURE REVIEW}

Financial inclusion is defined as access to and use of formal financial services by both households and companies and is crucial for economic development (Fungáčová \& Weill, 2015; Sahay et al., 2015). Financial inclusion helps reduce poverty (Ho and Iyke, 2018). Financial inclusion can provide opportunities for individuals to have a safe place to save for the future and encourages financial stability (Han and Melecky, 2013). Also, financial inclusion helps drive economic growth by increasing the likelihood of more significant investment in both education and entrepreneurship (Fungáčová and Weill, 2015). Therefore, financial inclusion as a policy is directed more to the poor households, who lack access to financial services.

Saving money, accessing credit, and managing financial risk are the main aspects of financial inclusion. There are three indicators commonly used by researchers to determine the level of financial inclusion. These indicators include formal accounts, formal saving, and formal credit (Demirguc-Kunt et al., 2018; Fungáčová and Weill, 2015). Simultaneously, the financial inclusion ecosystem consists of four components: access, use, quality, and welfare (Kabakova and Plaksenkov, 2018).

Formal credit is defined as credit received through formal financial institutions regulated by the government (Demirguc-Kunt et al., 2018; Li et al., 2011). Account ownership becomes a pathway to enter the formal financial sector in order to be able to take advantage of formal financial services such as credit. Easily accessible and affordable formal financial services are a hallmark of an inclusive financial system (Demirgüç-Kunt and Klapper, 2013). The amount of interest and terms of credit provided by formal financial institutions are regulated by the government, unlike informal credit. The interest rate cannot be controlled but has better flexibility.

As the first step in utilizing financial services, increasing account ownership is the focus of governments in most developing countries to reduce poverty (Han and Melecky, 2013). Nevertheless, credit and savings programs that have been implemented in many countries are still widely debated because they have not been able to reach the poor (Burgess et al., 2005). That requires policies and synergy between public and private institutions. In developing strategies for increasing financial inclusion, it is crucial to consider several aspects, such as social, economic, digital, and political, leading to better financial inclusion (Kabakova and Plaksenkov, 2018).

To increase financial inclusion, the Indonesian government introduced several policies, one of which was establishing the National Financial Inclusion Council (DNKI), chaired by the President of the Republic of Indonesia. ${ }^{4}$ The DNKI is tasked with coordinating and synchronizing the National Financial Inclusive Strategy (SNKI) implementation, directing steps and policies for solving problems and obstacles in implementing the SNKI, and monitoring and evaluating the implementation of the SNKI. The government has also formed Tim Percepatan Akses Keuangan Daerah (TPAKD), or a regional financial access acceleration team at

4 DNKI was formed based on Presidential Regulation of the Republic of Indonesia Number 82 the Year 2016 Concerning National Inclusive Financial Strategy. The President is chairman of the steering committee, while the daily chairman is occupied by the Republic of Indonesia's Coordinating Minister. 
the local authority level, as a forum for coordination between related stakeholders to support the policy.

The main objective of "bank the unbanked" efforts is to reduce the shortterm credit costs of low-income households by providing access to credit that is more affordable (either credit cards or bank loans) than moneylenders or informal financial institutions. Fitzpatrick (2013) documented that informal credit decreases following an increase in bank account holding among households, which previously did not have a bank account. Account ownership increases access to affordable credit through credit card ownership. Hogarth and O'Donnell (1999) also found that when households that previously did not have a bank account switched to bank accounts, credit cards' demand tripled, and that the demand for car loans, consumer loans, and savings products also increased. When lowerincome households that previously did not have an account then received a savings account, they would use other financial products offered by financial institutions and become a more viable customer collection. According to Li (2018), poor households are more likely to use loans more rationally, such as increasing welfare or investment, than imitating the consumption of the rich. ${ }^{5}$

However, different results are found in research in China (Fungáčová and Weill, 2015). The study explains that financial inclusion measured by account ownership in China is the highest among other emerging market countries, but formal credit ownership is still relatively low. Compared to other emerging market countries, formal credit is underdeveloped in China. Alternative loans from family or friends are still a habit compared to formal loans. Several studies have also shown that formal credit and informal credit do not perfectly substitute. The existence of formal credit can reduce informal credit but not fully replace it (Diagne, 1999; Giné, 2011; Mohieldin and Wright, 2000). Account ownership does not necessarily increase household preference to have credit, even though the objective of financial inclusion is to make it easier for people to get access to financial loans.

The availability of financial institutions also influences financial inclusion, especially loans. The closer and more evenly the spread of financial institutions, the more likely it will be to increase financial inclusion, especially for the poor or low-income earners, making it easier for them to get loans (Brown et al., 2016; Carletti et al., 2018). Research in India shows a considerable influence in terms of changes in income of the poor, especially women, due to microfinance. Moreover, financial inclusion has succeeded in driving financial inclusion in India (Swamy, 2014). However, the government banking program has not answered whether the program has succeeded in increasing bank loans to the poor (Burgess et al., 2005).

It is necessary to expand access to accommodate the demand or need for financial services, especially in rural areas (Kumar et al., 2019). The key to a financial inclusion program's success in reaching poor households is by providing good communication and transportation infrastructure, expanding the branch network of rural financial institutions, and directing loans to the poor (Beck et al., 2007; Burgess et al., 2005).

\footnotetext{
5 The comparative effect of using credit by the poor to follow the consumption style of the rich is known as the "keeping up with the jones" effect, whereas the "tunnel" effect connotets the situation whereby the poor use credit for investment because the success of the rich inspires them (Li, 2018).
} 
Every household has different demographic and geographic characteristics and also various environmental conditions. Several studies were conducted to compare financial inclusion in various countries and household behavior in accessing financial services (Allen et al., 2016; Demirgüç-Kunt and Klapper, 2013; Honohan, 2008). The research shows that half of the adults worldwide still do not have a savings account. In low-income countries, the concern is not about how much assets low-income households have but whether they have access to financial institutions. In the Southeast Asia countries, such as Vietnam, Indonesia, and the Philippines, access to formal savings and credit is still relatively low (Esquivias et al., 2020). Several barriers, such as lack of money, high financial costs, and financial services' perception pose challenges in developing financial inclusion in these countries. Formal and informal financial services coexist in these countries. Informal finance is still dominant and preferred to formal finance, especially for low-income and less educated people (Esquivias et al., 2020; Gitaharie et al., 2014). Therefore, formal credit can reduce informal credit but not fully replace it (Diagne, 1999).

As well as account ownership, access to credit is one of the main services provided by financial institutions. Therefore, household credit is also affected by both the supply and demand sides (Gitaharie et al., 2014; Kumar et al., 2019). On the supply side, credit is affected by financial institutions' penetration, which consists of financial institutions' existence or availability as a proxy for distance. Some studies suggested that formal financial institutions can improve access to finance to becomes more accessible for people to received financial services, especially credit (Carletti et al., 2018; Kumar et al., 2019). The closer the financial institutions are, the easier it is for people to access financial services, so that the probability of people receiving formal credit will also high (Allen et al., 2016).

Not only from the supply side, but it is also essential to include demandside factors such as household characteristics as a factor affecting households' decisions to utilize loan services provided by formal financial institutions. From the demand side, credit is affected by account ownership, demographic and socioeconomic characteristics of households, digital access, and household assets ownership (Fitzpatrick, 2013; Gitaharie et al., 2014; Li et al., 2011). Meanwhile, other factors, such as culture and religion, do not affect financial inclusion (Mylonidis et al., 2019). According to Akudugu (2013), several demographic factors, including age, wealth level, distance, literacy, and trust level, significantly affect a person's financial access preference. In India, gender plays a vital role in financial inclusion, especially in poor households (Ghosh and Vinod, 2017; Swamy, 2014).

\section{DATA AND METHODS}

Our study uses the 2018 National Socio-Economic Survey (Susenas) and Village Potential (Podes) datasets to analyze the effect of account ownership and financial institutions' existence on formal and informal household credit. Susenas contains the socio-demographic characteristics of the households. In contrast, the Podes dataset contains the characteristics of the area; that is, where the research subject (households) lives, at the village/urban-village level. Both data are merged according to the village/urban-village code contained in both data. This study's 
focus is on households in 34 provinces in Indonesia. In all, we gathered a total sample of 294,426 households for our analysis.

This study's dependent variable is credit, ownership of loans, or loans received by households last year. In the survey, the credit variable consists of three responses (or categories): do not receive loans, informal loans, and formal loans. Then, the independent variables of interest are: the dummy variable of account ownership; and the existence/ availability of financial institutions represented by three dummy variables to depict commercial banks (government, private, or bank agents), rural banks/Bank Perkreditan Rakyat (BPR), and cooperatives that serve credit (village unit cooperative, saving and loan cooperative or baitul maal wa tamwil ${ }^{6}$. Control variables include socio-demographic condition of households, digital access, and household assets. These are based on several studies (Allen et al., 2016; Demirgüç-Kunt \& Klapper, 2013; Fungáčová \& Weill, 2015; Gitaharie et al., 2014; Honohan, 2008; Swamy, 2014). Table 1 presents a data description of the variables used in this research.

Table 1.

Data Description

This table clarifies the details and source of the data used for the empirical analysis.

\begin{tabular}{|c|c|c|}
\hline Variable & Definition & Source of Data \\
\hline \multicolumn{3}{|c|}{ Outcome Variable } \\
\hline Credit & $\begin{array}{l}\text { Household credit ownership; } 1 \text { if do not own credit } 2 \text { if own } \\
\text { informal credit and } 3 \text { if own formal credit }\end{array}$ & Susenas 2018 \\
\hline \multicolumn{3}{|c|}{ Interest Variable: Account Ownership } \\
\hline Account & $\begin{array}{l}\text { Dummy variable for household account ownership; } 1 \text { for own } \\
\text { account (bank or Cooperative); } 0 \text { for the other }\end{array}$ & Susenas 2018 \\
\hline \multicolumn{3}{|c|}{ Interest Variable: The Existence/Availability of Financial Institutions } \\
\hline Bank & $\begin{array}{l}\text { Dummy variable for Commercial Banks (Public, Private or Bank } \\
\text { Agent); } 1 \text { if there is one or more bank in the village/urban-village } \\
\text { where the household lives; } 0 \text { for the other }\end{array}$ & Podes 2018 \\
\hline BPR & $\begin{array}{l}\text { Dummy variable for BPR or Rural Bank; } 1 \text { if there is one or more } \\
\text { rural bank in the village/urban-village where the household } \\
\text { lives; } 0 \text { for the other }\end{array}$ & Podes 2018 \\
\hline Cooperative & $\begin{array}{l}\text { Dummy variable for Cooperative (that serve credit) or Credit } \\
\text { Union; } 1 \text { if there is one or more Cooperative in the village/urban- } \\
\text { village where the household lives; } 0 \text { for the other }\end{array}$ & Podes 2018 \\
\hline \multicolumn{3}{|c|}{ Control Variable: Socioeconomic and Demographic Characteristics } \\
\hline Urban & Dummy variable for Location; 1 for Urban; 0 for the other & Susenas 2018 \\
\hline Poor & $\begin{array}{c}\text { Dummy variable for the poor household; } 1 \text { for Poor; } 0 \text { for the } \\
\text { other }\end{array}$ & Susenas 2018 \\
\hline Gender & $\begin{array}{l}\text { Dummy variable for the gender of head of household; } 1 \text { for } \\
\text { Male; } 0 \text { for the other }\end{array}$ & Susenas 2018 \\
\hline Married & $\begin{array}{l}\text { Dummy variable for the marital status of head of household; } 1 \\
\text { for married; } 0 \text { for the other }\end{array}$ & Susenas 2018 \\
\hline
\end{tabular}

6 Baitul Maal wa Tamwil (BMT) is a microfinance institution (in the form of cooperative) in Indonesia that operate based on Islamic Law (sharia). 
Table 1.

Data Description (Continued)

\begin{tabular}{|c|c|c|}
\hline Variable & Definition & Source of Data \\
\hline Age & $\begin{array}{l}\text { Dummy variable for Age of head of household; } 1 \text { if Age of head } \\
\text { of household between } 15 \text { and } 64 \text { years; } 0 \text { for the other }\end{array}$ & Susenas 2018 \\
\hline Education & $\begin{array}{l}\text { Dummy variable for last education of the head of household; } 1 \\
\text { if do not graduate from elementary school; } 2 \text { if graduate from } \\
\text { elementary school; } 3 \text { if graduate from junior high school; } 4 \text { if } \\
\text { graduate from high school; } 5 \text { if graduate from college/ university }\end{array}$ & Susenas 2018 \\
\hline Size & Household size/number of a household member & Susenas 2018 \\
\hline Work & $\begin{array}{l}\text { Dummy variable for a working status of head of household; } 1 \\
\text { for work; } 0 \text { for the other }\end{array}$ & Susenas 2018 \\
\hline Entrepreneur & $\begin{array}{l}\text { Dummy variable for entrepreneur status of head of household; } 1 \\
\text { for the entrepreneur; } 0 \text { for the other }\end{array}$ & Susenas 2018 \\
\hline Pension & $\begin{array}{c}\text { Dummy variable for pension fund recipient; } 1 \text { for receive; } 0 \text { for } \\
\text { the other }\end{array}$ & Susenas 2018 \\
\hline School & $\begin{array}{l}\text { Dummy variable for school participation; } 1 \text { if one or more } \\
\text { household members are still in school; } 0 \text { for the other }\end{array}$ & Susenas 2018 \\
\hline \multicolumn{3}{|c|}{$\begin{array}{c}\text { Control Variable: Digital Access } \\
\end{array}$} \\
\hline Mobile & $\begin{array}{l}\text { Dummy variable for mobile phone ownership; } 1 \text { if the household } \\
\text { owns a mobile phone; } 0 \text { for the other }\end{array}$ & Susenas 2018 \\
\hline Internet & $\begin{array}{l}\text { Dummy variable for the use of the internet; } 1 \text { if a household uses } \\
\text { internet (in the last three month); } 0 \text { for the other }\end{array}$ & Susenas 2018 \\
\hline \multicolumn{3}{|c|}{ Control Variable: Asset Ownership } \\
\hline House & $\begin{array}{l}\text { Dummy variable for house ownership; } 1 \text { if the household owns } \\
\text { the house; } 0 \text { for the other }\end{array}$ & Susenas 2018 \\
\hline Land & $\begin{array}{l}\text { Dummy variable for land ownership; } 1 \text { if the household owns } \\
\text { the land; } 0 \text { for the other }\end{array}$ & Susenas 2018 \\
\hline Gold & $\begin{array}{l}\text { Dummy variable for gold ownership; } 1 \text { if the household owns } \\
\text { gold; } 0 \text { for the other }\end{array}$ & Susenas 2018 \\
\hline Car & $\begin{array}{l}\text { Dummy variable for car ownership; } 1 \text { if the household owns a } \\
\qquad \text { car; } 0 \text { for the other }\end{array}$ & Susenas 2018 \\
\hline Motorcycle & $\begin{array}{l}\text { Dummy variable for motorcycle ownership; } 1 \text { if the household } \\
\text { owns motorcycle; } 0 \text { for the other }\end{array}$ & Susenas 2018 \\
\hline
\end{tabular}

The multinomial logit regression is employed to estimate the probability that household loans depend on account ownership and financial institutions' availability. Multinomial logit regression is a form of regression whereby the response results are not binary or two outcomes but more than two outcomes (Gujarati and Porter, 2004). There are three categories in the dependent variable (no credit, informal credit, and formal credit). Multinomial logit is estimated using maximum likelihood, and parameter interpretation is conducted using marginal effect for a discrete change of dummy variables from zero to one. The model that will be used in this study is as follows:

$$
\text { Credit }_{i j}=\beta_{0}+\beta_{1} \text { Account }_{i}+\beta_{2} \text { Availability }_{j}+\beta_{3} \text { Control }_{i}+\varepsilon_{i j}
$$


where, Credit ${ }_{i j}$ denotes credit of household $i$ in village/urban-village $j$. Account is a dummy variable for household account ownership and Availability is a vector of dummy variables for the existence/availability of financial institutions consisting of commercial banks, BPR, and cooperatives. Control ${ }_{i}$ represents a vector of control variables such as socioeconomic and demographic characteristics, digital access, and asset ownership, as explained in Table 1 . Our main concern is $\beta_{1}$ and $\beta_{2^{\prime}}$ which give us information on the relationship between account ownership and the availability of financial institutions and household credit.

\section{RESULTS AND DISCUSSION}

We begin our discussion by examining the descriptive statistics and cross tabulation results. We present the descriptive statistics in Table 2. In essence, we find that households in Indonesia who received formal credit were $23.60 \%$, while only $1.76 \%$ of the households chose informal credit. At the same time, households that have accounts in formal financial institutions reached $58.18 \%$. Commercial banks and bank agents are the formal financial institutions the most evenly distributed throughout the villages, making them the most accessible to the society. As many as $59.42 \%$ of the households have access to commercial banks or bank agents in their villages. Cooperatives consisting of Koperasi Unit Desa (KUD), Koperasi Simpan Pinjam (KSP), and Baitul Maal wa Tamwil (BMT) are the second most evenly distributed financial institutions. Approximately $44.79 \%$ of households have access to cooperatives in the villages where they live. In addition, as much as $16.11 \%$ of the households have access to BPR (see Table 2).

Table 2.

\section{Descriptive Statistics}

This table presents the distribution of household characteristics and the characteristics of the residential area of the sampled households with a response $=1$ for each dummy variable define in Table 1 .

\begin{tabular}{lccc}
\hline Variable & & $\mathbf{N}$ & Percentage \\
\hline $\mathbf{( 1 )}$ & & $\mathbf{( 2 )}$ & $\mathbf{( 3 )}$ \\
\hline Credit & Informal Credit & 5,183 & 1.76 \\
& Formal Credit & 69,485 & 23.60 \\
Account & & 171,297 & 58.18 \\
Bank & & 174,954 & 59.42 \\
BPR & & 47,445 & 16.11 \\
Cooperative & & 131,876 & 44.79 \\
Urban & & 161,190 & 54.75 \\
Poor & & 23,400 & 7.95 \\
Gender & & 249,763 & 84.83 \\
Married & & 237,011 & 80.50 \\
Age & & 255,632 & 86.82 \\
Education & & 83,754 & 28.45 \\
& Elementary School & 46,077 & 15.65 \\
& Junior High School & 72,341 & 24.57 \\
Work & High School & 24,655 & 8.37 \\
\hline
\end{tabular}


Table 2.

Descriptive Statistics (Continued)

\begin{tabular}{lcc}
\hline Variable & $\mathbf{N}$ & Percentage \\
\hline $\mathbf{( 1 )}$ & $\mathbf{( 2 )}$ & $\mathbf{( 3 )}$ \\
\hline Entrepreneur & 125,345 & 42.57 \\
Pension & 25,759 & 8.75 \\
School & 167,291 & 56.82 \\
Mobile & 264,589 & 89.87 \\
Internet & 195,048 & 66.25 \\
House & 235,613 & 80.02 \\
Land & 208,757 & 70.90 \\
Gold & 53,758 & 18.26 \\
Car & 33,788 & 11.48 \\
Motorcycle & 225,889 & 76.72 \\
\hline
\end{tabular}

Although most households do not receive credit, account ownership could provide households with greater credit access, especially formal credit. The percentage of households that did not receive credit was greater for households $(84.83 \%)$ that did not have accounts than households with accounts $(67.31 \%)$ (see Table 4). In other words, the households that received formal credit were more significant for households with accounts than households that did not have accounts. The result implies that account ownership provides better access to credit, in particular formal credit. Households make these accounts an intermediary of accessing formal credit to no longer depend on informal credit (Fitzpatrick, 2013; Hogarth and O'Donnell, 2000).

Table 3 shows the correlation between variables, while Table 4 shows the crosstabulation between dependent and independent variables.

The key messages from Table 4 are as follows. The existence of formal financial institutions could encourage people to received formal credit. The percentage of formal credit is more significant for households in villages/urban-villages with formal financial institutions than for households without formal financial institutions in their villages/urban-villages. Households in the villages/urbanvillages with a commercial bank (or bank agent), BPR, and a cooperative have a more significant formal credit percentage than those in villages/urban-villages without a formal financial institution. Households in the villages with financial institutions have a smaller percentage of informal credit than those in villages without financial institutions. This indicates that formal financial institutions can reduce informal credit in society, even though the difference is not very large. This is consistent with previous research stating that formal financial institutions' existence provides easier access to formal credit to the community, which will impact poverty reduction (Burgess et al. 2005). 


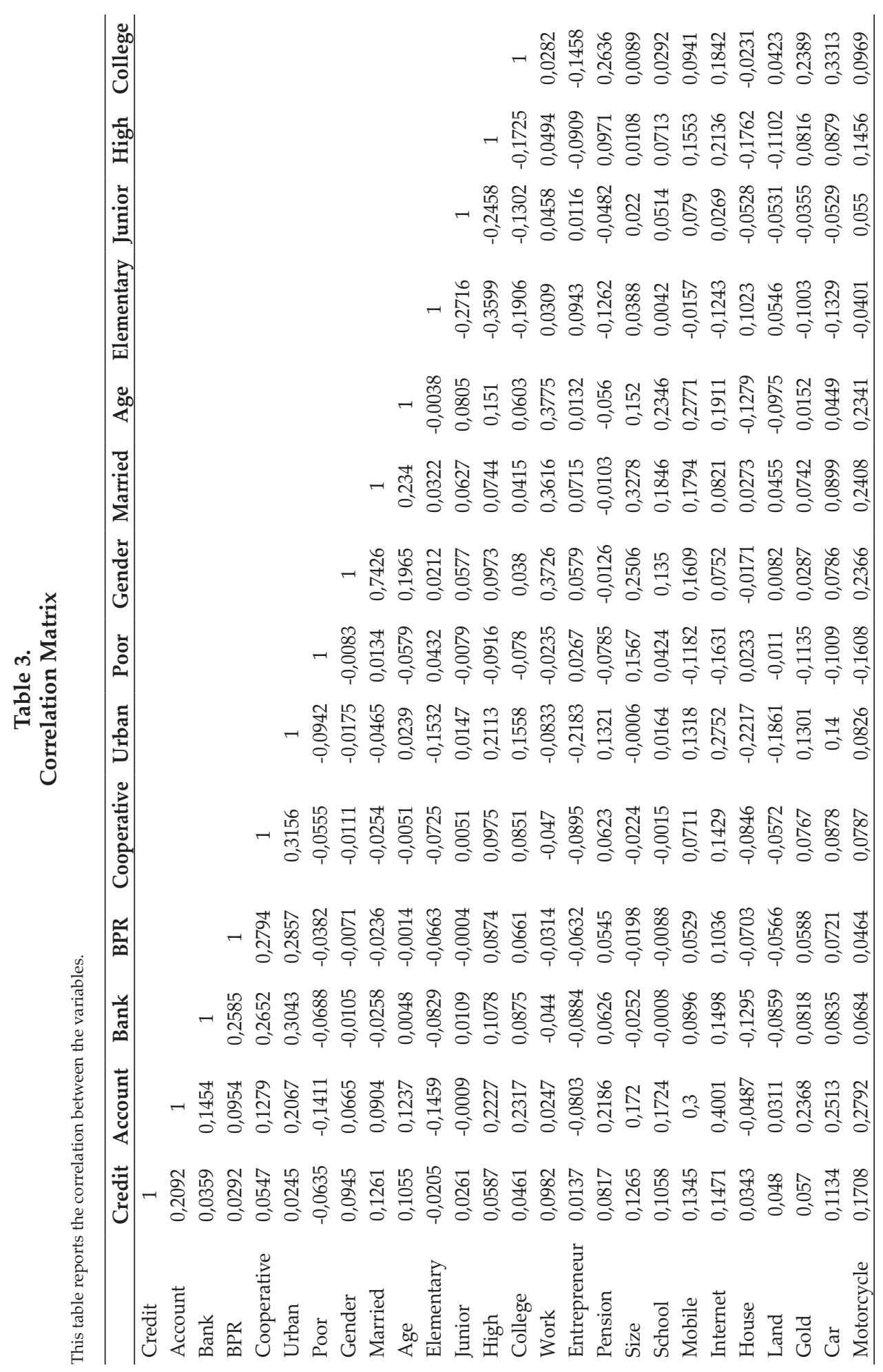




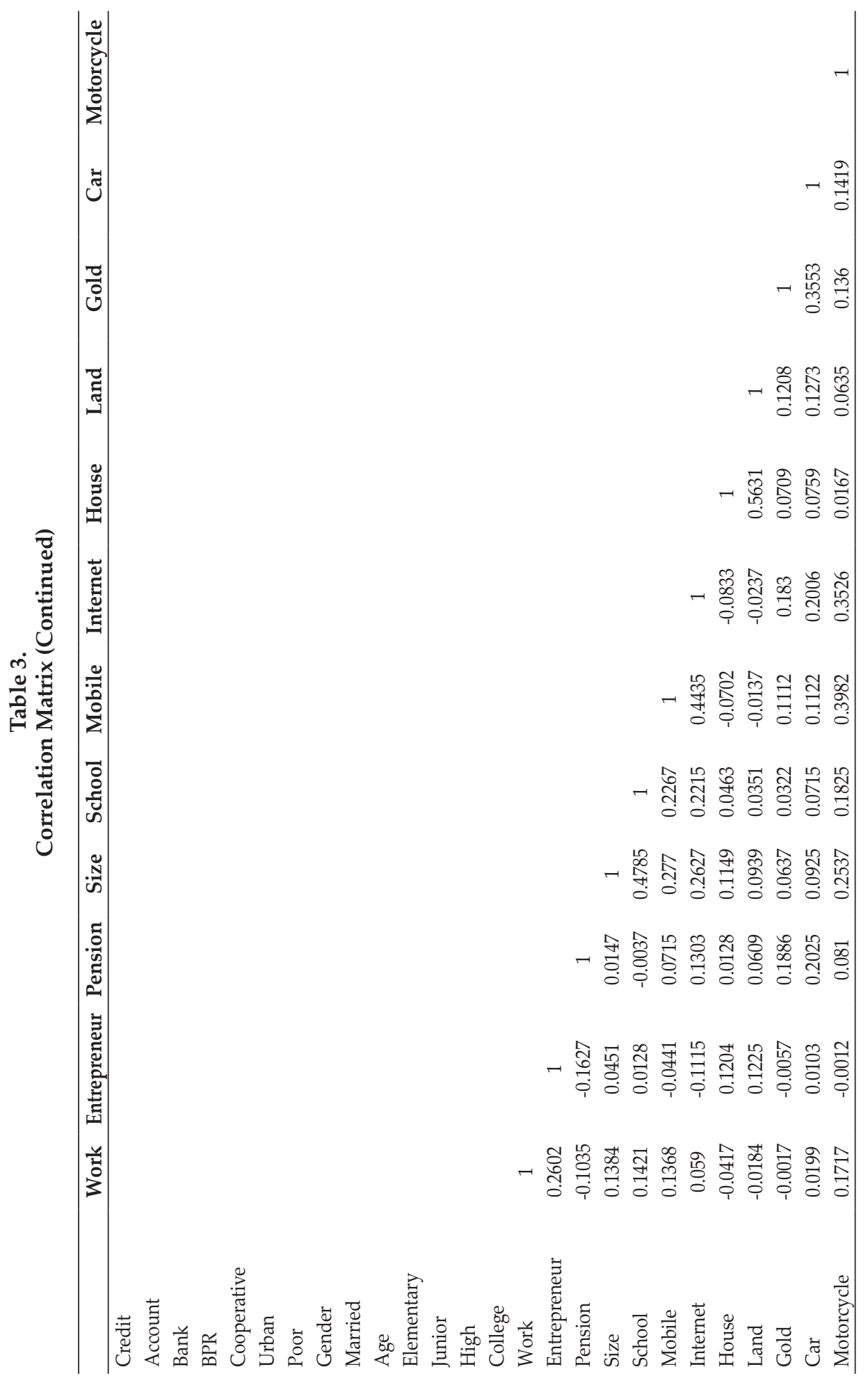


Table 4.

Cross Tabulation

Tabulation calculates in percentage (\%). Source: The 2018 Susenas and 2018 Podes (processed with weighing)

\begin{tabular}{|c|c|c|c|c|c|}
\hline \multirow[t]{2}{*}{ Variable } & \multicolumn{2}{|c|}{ Receive Credit } & \multicolumn{3}{|c|}{ Type of Credit } \\
\hline & No & Yes & No Credit & $\begin{array}{c}\text { Informal } \\
\text { Credit }\end{array}$ & $\begin{array}{l}\text { Formal } \\
\text { Credit }\end{array}$ \\
\hline (1) & (2) & (3) & $(4)$ & (5) & (6) \\
\hline \multicolumn{6}{|c|}{ Banked: Account Ownership in Bank / Cooperative } \\
\hline Own an account & 67.31 & 32.69 & 67.31 & 1.35 & 31.34 \\
\hline Do not own an account & 84.83 & 15.17 & 84.83 & 2.34 & 12.83 \\
\hline \multicolumn{6}{|c|}{ Availability: Existence / Availability of Financial Institutions } \\
\hline Bank & 73.42 & 26.58 & 73.42 & 1.67 & 24.90 \\
\hline No Commercial Bank & 76.42 & 23.58 & 76.42 & 1.89 & 21.69 \\
\hline $\mathrm{BPR}$ & 71.94 & 28.06 & 71.94 & 1.49 & 26.57 \\
\hline No BPR & 75.16 & 24.84 & 75.16 & 1.81 & 23.03 \\
\hline Cooperative & 72.15 & 27.85 & 72.15 & 1.58 & 26.27 \\
\hline No Cooperative & 76.66 & 23.34 & 76.66 & 1.91 & 21.43 \\
\hline \multicolumn{6}{|c|}{ Control: Demographic and Social Economic Characteristics } \\
\hline Urban & 73.77 & 26.23 & 73.77 & 1.60 & 24.63 \\
\hline Rural & 75.69 & 24.31 & 75.69 & 1.95 & 22.36 \\
\hline Poor Household & 83.39 & 16.61 & 83.39 & 2.63 & 13.98 \\
\hline Not a Poor Household & 73.88 & 26.12 & 73.88 & 1.68 & 24.43 \\
\hline Male & 72.93 & 27.07 & 72.93 & 1.79 & 25.28 \\
\hline Female & 84.21 & 15.79 & 84.21 & 1.60 & 14.19 \\
\hline Married & 71.96 & 28.04 & 71.96 & 1.84 & 26.20 \\
\hline Not/Not yet Married & 85.70 & 14.30 & 85.70 & 1.42 & 12.88 \\
\hline Productive Age & 72.86 & 27.14 & 72.86 & 1.84 & 25.31 \\
\hline Not in Productive Age & 86.39 & 13.61 & 86.39 & 1.26 & 12.35 \\
\hline Not School & 79.56 & 20.44 & 79.56 & 2.32 & 18.12 \\
\hline Elementary School & 75.85 & 24.15 & 75.85 & 2.11 & 22.04 \\
\hline Junior High School & 71.92 & 28.08 & 71.92 & 2.05 & 26.03 \\
\hline High School & 70.57 & 29.43 & 70.57 & 1.16 & 28.27 \\
\hline College & 68.79 & 31.21 & 68.79 & 0.51 & 30.70 \\
\hline Work & 72.72 & 27.28 & 72.72 & 1.87 & 25.41 \\
\hline Not Work & 84.25 & 15.75 & 84.25 & 1.21 & 14.54 \\
\hline Entrepreneur & 73.89 & 26.11 & 73.89 & 1.91 & 24.20 \\
\hline Not Entrepreneur & 75.20 & 24.80 & 75.20 & 1.65 & 23.15 \\
\hline Receive pension & 64.04 & 35.96 & 64.04 & 0.54 & 35.43 \\
\hline Not Receive pension & 75.66 & 24.34 & 75.66 & 1.88 & 22.47 \\
\hline School Participation & 70.65 & 29.35 & 70.65 & 1.90 & 27.45 \\
\hline No School Participation & 79.89 & 20.11 & 79.89 & 1.58 & 18.53 \\
\hline \multicolumn{6}{|c|}{ Control: Digital Access } \\
\hline Own Mobile Phone & 72.72 & 27.28 & 72.72 & 1.76 & 25.52 \\
\hline Not Own Mobile Phone & 91.65 & 8.35 & 91.65 & 1.76 & 6.59 \\
\hline Using Internet & 70.28 & 29.72 & 70.28 & 1.55 & 28.17 \\
\hline Not Using internet & 83.19 & 16.81 & 83.19 & 2.17 & 14.64 \\
\hline
\end{tabular}


Table 4.

Cross Tabulation (Continued)

\begin{tabular}{lccccc}
\hline Variable & \multicolumn{3}{c}{ Receive Credit } & \multicolumn{3}{c}{ Type of Credit } \\
\cline { 2 - 6 } & No & Yes & No Credit & $\begin{array}{c}\text { Informal } \\
\text { Credit }\end{array}$ & $\begin{array}{c}\text { Formal } \\
\text { Credit }\end{array}$ \\
\hline $\mathbf{( 1 )}$ & $\mathbf{( 2 )}$ & $\mathbf{( 3 )}$ & $\mathbf{( 4 )}$ & $\mathbf{( 5 )}$ & $\mathbf{( 6 )}$ \\
\hline House & \multicolumn{2}{c}{ Control: Asset Ownership } & & \\
Not own a House & 73.93 & 26.07 & 73.93 & 1.71 & 24.35 \\
Land & 77.47 & 22.53 & 77.47 & 1.94 & 20.59 \\
Not own a Land & 73.40 & 26.60 & 73.40 & 1.62 & 24.98 \\
Gold & 77.65 & 22.35 & 77.65 & 2.11 & 20.24 \\
Not own a Gold & 69.98 & 30.02 & 69.98 & 0.84 & 29.18 \\
Car & 75.68 & 24.32 & 75.68 & 1.97 & 22.35 \\
Not own a Car & 61.87 & 38.13 & 61.87 & 0.56 & 37.58 \\
Motorcycle & 76.30 & 23.70 & 76.30 & 1.92 & 21.79 \\
Not own Motorcycle & 70.71 & 29.29 & 70.71 & 1.62 & 27.67 \\
\hline
\end{tabular}

Next, we present results from our model estimated using the multinomial logit regression method. The total number of observations was 294,426, while the Chi-squared test (Prob>chi2) yields a $p$-value of 0.000, which means that all independent variables used in the model simultaneously affect the dependent variable, credit ownership. The McFadden Pseudo R-squared value is 0.079, which means that the variation of the credit variable can be explained by $7.9 \%$ of the variation in the independent variables. We also perform a robustness test by using several different models with different control variables according to their characteristics (see results in Table 5). Table 6 presents the marginal effect, which shows the discrete change of dummy variables from zero to one.

Based on the results, account ownership significantly affects households' probability of receiving credit from formal financial institutions. Table 5 shows that the household account ownership variable is positively correlated to the credit variable even after controlling for other variables. We also conducted a robustness check using the Java variable ( $1=$ Java island, $0=$ others) and found similar results (see Appendix 1). When households have a bank or cooperative account, their probability of getting credit through formal institutions increased by $12.56 \%$ (see Table 6 ). Otherwise, the households' probability of not receiving credit decreased by $12.16 \%$. Moreover, the households' probability to received informal credit decreased by $0.40 \%$. This means that households with accounts will tend to receive credit from formal financial institutions and avoid informal credit, assuming other variables are constant (ceteris paribus). These results confirm some of the previous research, which found that account ownership provides access to broader financial services, thereby reducing the likelihood of loans from informal sources that are detrimental to household wealth creation (Demirguc-Kunt et al., 2018; Fitzpatrick, 2013). Furthermore, the results imply that account ownership is needed to increase financial services, especially credit. Therefore, a government strategy must increase account ownership to reduce informal credit and improve formal credit. 
Tabel 5.

Multinomial Logit Regression Results

This table reports multinomial logit regresstion results with different control variables. Standard errors are in parentheses ${ }^{*} \mathrm{p}<0.10,{ }^{* *} \mathrm{p}<0.05,{ }^{* * *} \mathrm{p}<0.01$. Source: The 2018 Susenas and 2018 Podes (processed with weighing)

\begin{tabular}{|c|c|c|c|c|}
\hline & (1) & (2) & (3) & (4) \\
\hline \multicolumn{5}{|l|}{ Informal Credit } \\
\hline \multicolumn{5}{|c|}{ Banked: Account Ownership in Bank / Cooperative } \\
\hline Account & $\begin{array}{c}-0.291^{* * *} \\
(0.0291)\end{array}$ & $\begin{array}{c}-0.172^{* * *} \\
(0.0307)\end{array}$ & $\begin{array}{c}-0.169^{* * *} \\
(0.0315)\end{array}$ & $\begin{array}{c}-0.0994^{* * *} \\
(0.0316)\end{array}$ \\
\hline \multicolumn{5}{|c|}{ Availability: Existence / Availability of Financial Institutions } \\
\hline Bank & $\begin{array}{c}0.0125 \\
(0.0307)\end{array}$ & $\begin{array}{l}0.0566^{*} \\
(0.0307)\end{array}$ & $\begin{array}{l}0.0557^{*} \\
(0.0307)\end{array}$ & $\begin{array}{l}0.0554^{*} \\
(0.0308)\end{array}$ \\
\hline BPR & $\begin{array}{l}-0.0645 \\
(0.0441)\end{array}$ & $\begin{array}{l}-0.0309 \\
(0.0442)\end{array}$ & $\begin{array}{l}-0.0310 \\
(0.0443)\end{array}$ & $\begin{array}{l}-0.0263 \\
(0.0443)\end{array}$ \\
\hline Cooperative & $\begin{array}{l}-0.0574^{*} \\
(0.0312)\end{array}$ & $\begin{array}{l}-0.0160 \\
(0.0313)\end{array}$ & $\begin{array}{l}-0.0139 \\
(0.0313)\end{array}$ & $\begin{array}{l}-0.00216 \\
(0.0314)\end{array}$ \\
\hline Urban & $\begin{array}{c}-0.0845^{* * *} \\
(0.0313)\end{array}$ & $\begin{array}{l}0.0618^{*} \\
(0.0322)\end{array}$ & $\begin{array}{l}0.0745^{* *} \\
(0.0325)\end{array}$ & $\begin{array}{c}0.0484 \\
(0.0333)\end{array}$ \\
\hline $\begin{array}{l}\text { Control: Demographic and Social Economic } \\
\text { Characteristics (9) }\end{array}$ & & $\checkmark$ & $\checkmark$ & $\checkmark$ \\
\hline Control: Digital Access (2) & & & $\checkmark$ & $\checkmark$ \\
\hline Control: Asset Ownership (5) & & & & $\checkmark$ \\
\hline Constant & $\begin{array}{l}-3.536^{* * *} \\
(0.0256)\end{array}$ & $\begin{array}{l}-4.544^{* * *} \\
(0.0672)\end{array}$ & $\begin{array}{l}-4.655^{* * *} \\
(0.0719)\end{array}$ & $\begin{array}{l}-4.494^{* * *} \\
(0.0808)\end{array}$ \\
\hline \multirow{2}{*}{\multicolumn{5}{|c|}{ Banked: Account Ownership in Bank / Cooperative }} \\
\hline & & & & \\
\hline Account & $\begin{array}{l}1.132^{* * *} \\
(0.0102)\end{array}$ & $\begin{array}{l}0.938^{* * *} \\
(0.0110)\end{array}$ & $\begin{array}{l}0.846^{* * *} \\
(0.0112)\end{array}$ & $\begin{array}{l}0.802^{* * *} \\
(0.0114) \\
\end{array}$ \\
\hline \multicolumn{5}{|c|}{ Availability: Existence / Availability of Financial Institutions } \\
\hline Bank & $\begin{array}{c}0.0228^{* *} \\
(0.00995)\end{array}$ & $\begin{array}{c}0.0419^{* * *} \\
(0.0101)\end{array}$ & $\begin{array}{c}0.0286^{* * *} \\
(0.0101)\end{array}$ & $\begin{array}{c}0.0381^{* * *} \\
(0.0102)\end{array}$ \\
\hline BPR & $\begin{array}{c}0.0514^{* * *} \\
(0.0127)\end{array}$ & $\begin{array}{c}0.0681^{* * *} \\
(0.0129)\end{array}$ & $\begin{array}{c}0.0650^{* * *} \\
(0.0129)\end{array}$ & $\begin{array}{c}0.0552^{* * *} \\
(0.0129)\end{array}$ \\
\hline Cooperative & $\begin{array}{c}0.176^{* * *} \\
(0.00972)\end{array}$ & $\begin{array}{c}0.202^{* * *} \\
(0.00989)\end{array}$ & $\begin{array}{c}0.192^{* * *} \\
(0.00989)\end{array}$ & $\begin{array}{c}0.177^{* * *} \\
(0.00994)\end{array}$ \\
\hline Urban & $\begin{array}{l}-0.167^{* * *} \\
(0.0101)\end{array}$ & $\begin{array}{l}-0.144^{* * *} \\
(0.0106)\end{array}$ & $\begin{array}{l}-0.183^{* * *} \\
(0.0107)\end{array}$ & $\begin{array}{l}-0.139^{* * *} \\
(0.0109)\end{array}$ \\
\hline $\begin{array}{l}\text { Control: Demographic and Social Economic } \\
\text { Characteristics (9) }\end{array}$ & & $\checkmark$ & $\checkmark$ & $\checkmark$ \\
\hline Control: Digital Access (2) & & & $\checkmark$ & $\checkmark$ \\
\hline Control: Asset Ownership (5) & & & & $\checkmark$ \\
\hline Constant & $\begin{array}{l}-1.905^{* * *} \\
(0.0103)\end{array}$ & $\begin{array}{l}-3.485^{* * *} \\
(0.0253)\end{array}$ & $\begin{array}{l}-3.943^{* * *} \\
(0.0319)\end{array}$ & $\begin{array}{r}-4.259^{* * * *} \\
(0.0349)\end{array}$ \\
\hline Observations & 294426 & 294426 & 294426 & 294426 \\
\hline Pseudo R2 & 0.041 & 0.067 & 0.071 & 0.079 \\
\hline Chi2 & 15073.0 & 24880.7 & 26217.3 & 29160.7 \\
\hline
\end{tabular}


Tabel 6.

Marginal Effect

This table reports marginal effect results. Standard errors are in parentheses ${ }^{*} \mathrm{p}<0.10,{ }^{* *} \mathrm{p}<0.05,{ }^{* * *} \mathrm{p}<0.01$. Source: The 2018 Susenas and 2018 Podes (processed with weighing)

\begin{tabular}{|c|c|c|c|c|c|c|}
\hline \multirow[b]{2}{*}{ Variable } & \multicolumn{2}{|c|}{ No Credit } & \multicolumn{2}{|c|}{ Informal Credit } & \multicolumn{2}{|c|}{ Formal Credit } \\
\hline & $\mathrm{dy} / \mathrm{dx}$ & $\begin{array}{c}\text { Standard } \\
\text { Error }\end{array}$ & $\mathrm{dy} / \mathrm{dx}$ & $\begin{array}{c}\text { Standard } \\
\text { Error }\end{array}$ & $\mathrm{dy} / \mathrm{dx}$ & $\begin{array}{l}\text { Standard } \\
\text { Error }\end{array}$ \\
\hline \multicolumn{7}{|c|}{ Banked : Account Ownership in Bank/ Cooperative } \\
\hline Account & $-0.1216^{* * *}$ & 0.0017 & $-0.00399 * * *$ & 0.0005 & $0.1256^{* * *}$ & 0.00168 \\
\hline \multicolumn{7}{|c|}{ Availability: Existence / Availability of Financial Institutions } \\
\hline Bank & $-0.00671^{* * *}$ & 0.00168 & 0.00072 & 0.00046 & $0.005997^{* * *}$ & 0.00164 \\
\hline BPR & $-0.00857^{* * *}$ & 0.0022 & -0.00057 & 0.00066 & $0.00914^{* * *}$ & 0.00214 \\
\hline Cooperative & $-0.02835^{* * *}$ & 0.00167 & -0.000595 & 0.00047 & $0.02894^{* * *}$ & 0.00163 \\
\hline $\begin{array}{l}\text { Control: Den } \\
\text { Economic } \mathrm{Cl}\end{array}$ & & $\checkmark$ & $\checkmark$ & 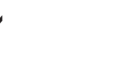 & $\checkmark$ & \\
\hline Control: Digi & & $\checkmark$ & v & & v & \\
\hline Control: Asse & & $\checkmark$ & $\checkmark$ & 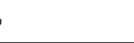 & $\checkmark$ & \\
\hline
\end{tabular}

Commercial banks or bank agents' existence significantly influences households' probability of receiving credit from formal financial institutions but does not significantly influence households to receive informal credit. There is a positive but not too strong relationship between commercial banks and informal credit, indicating competition between informal credit and formal credit and that formal and informal credit are perfect substitutes (Giné, 2011). When a bank or bank agent is in the village, the chances of households living in that village receiving formal credit increases by $0.60 \%$. While the households' chances of not obtaining credit will decrease by $0.67 \%$. Thus, it can be concluded that households in the villages with existing banks or bank agents are more likely to get formal credit.

The existence of rural banks (BPR) significantly affects households' probability of receiving credit from formal financial institutions but does not significantly affect informal loans. The existence of BPR is positively correlated with formal credit. The existence of rural banks increases households' chances of receiving credit from informal financial institutions by $0.91 \%$ and decreases the chances of households not receiving credit by $0.86 \%$. This indicates that households in the villages with BPR are more likely to receive formal credit. The existence of BPR increases formal credit but does not necessarily reduce informal credit.

Just like BPR, the existence of cooperatives in the form of village unit cooperatives (Koperasi Unit Desa/KUD), which provide business credit, savings, and credit cooperatives (Koperasi Simpan Pinjam/KSP) or Baitul Maal wa Tamwil (BMT), significantly influences the probability of households to receive formal credit but does not significantly affect informal credit. The existence of cooperatives is positively correlated with formal credit. When a cooperative is in the village, the probability of households living in that villages to received formal credit increases by $2.89 \%$, while the probability of households not to receive credit decreases by $2.84 \%$, indicating that households in the villages that have cooperatives are more likely to receive formal credit. These results indicate that, other than banks, BPR 
and cooperatives can be sources of loans that can be utilized by communities, although both do not significantly reduce informal credit.

The effect of formal financial institutions on household credit based on the results above confirms some previous studies, which showed that the existence of banks can increase formal credit (Allen et al., 2016; Demirguc-Kunt et al., 2018; Fitzpatrick, 2013). When banks become accessible, so the barriers such as distance are reduced, formal financial institutions can accommodate the community's needs for better loans. Formal financial institutions in Indonesia have been able to enter the villages where households need loans. Also, formal financial institutions have extensive networks with a broad enough scope to encourage formal credit (Brown et al., 2016). Even so, formal financial institutions' existence did not entirely reduce informal credit, indicating that there is still less doubt from the public to borrow from informal financial institutions; hence, they still rely on informal credit. Other obstacles such as complicated procedures, flexibility, and administrative, and collateral requirements can be reasons for this reliance on informal credit (Gitaharie et al., 2014; Li et al., 2011).

This finding is also consistent with previous research claiming that formal financial institutions and informal lenders compete, but are not perfect substitutes (Diagne, 1999; Giné, 2011; Mohieldin and Wright, 2000). Therefore, the existence of financial institutions that provide formal credit services cannot wholly replace informal credit. Even the existence of financial institutions that provide formal credit does not necessarily reduce informal credit. The existence of formal financial institutions is still needed because they can significantly increase formal credit.

Encouraging account ownership is the best way to reduce informal credit and improve formal credit. Account ownership provides more affordable access to formal credit, so that people will be more likely to choose formal credit and avoid informal credit. In addition to the factors above, several other factors also affect informal and formal credit, based on our results. Households that are likely to receive informal credit are households with a female head, married, at a productive age, a low-educated, who works, does not receive a pension, and have more household members. Similarly, households that more likely to receive loans through formal institutions are households living in the rural areas, are not poor, have female heads, are married, at productive age, with elementary to high school education, working, entrepreneurs, pension recipient, and have more household members.

\section{CONCLUSION}

This study examines the influence of account ownership and access to financial institutions on access to credit in Indonesia. The study relies on primary survey data sourced from the 2018 National Social and Economic Survey (Survei Sosial dan Ekonomi Nasional/Susenas), and the 2018 Village Potential (Potensi Desa/Podes) received from the Central Statistics Agency (Badan Pusat Statistik/BPS) of the Republic of Indonesia. We estimate multinomial logit regressions using 294,426 households and find that there is a significant relationship between account ownership and both formal and informal credit. Households with accounts are more likely to receive loans from formal financial institutions and to avoid 
informal credit. Account ownership is essential for households to get access to other financial services such as formal credit.

From the supply side, we find that commercial banks-public, private, and bank agents-can increase formal credit, but do not significantly impact informal credit. In addition to banks, other financial institutions, such as BPR and cooperatives, have also increased households' opportunities to received loans from formal institutions. This indicates a competition between formal financial institutions and informal lenders and that formal credit cannot wholly replace informal credit. However, formal financial institutions' existence is still very much needed to provide formal credit.

Encouraging account ownership is the best way to reduce informal credit and to improve formal credit. Therefore, this study recommends that the government should encourage account ownership, especially for people who are still classified as unbanked, to reduce informal credit and improve formal credit. Furthermore, efforts to increase account ownership, such as giving education about formal finance and facilitating the opening of of bank accounts, should be pursued by policymakers. The government also needs to expand the access to financial institutions in order to reach people in need. In turn, this will improve access to formal finance, thereby increasing formal credit and reducing informal credit.

\section{REFERENCES}

Akudugu, M. (2013). The Determinants of Financial Inclusion in Western Africa : Insights from Ghana. Research Journal of Finance and Accounting ISSN 2222$2847,4,1-10$.

Allen, F., Demirguc-Kunt, A., Klapper, L., \& Martinez Peria, M. S. (2016). The Foundations of Financial Inclusion: Understanding Ownership and Use of Formal Accounts. Journal of Financial Intermediation, 27, 1-30. https://doi.org/10.1016/j.jfi.2015.12.003

Beck, T., Demirguc-kunt, A., Soledad, M., \& Peria, M. (2007). Reaching Out : Access to and Use of Banking Services Across Countries. Journal of Financial Economics, 85, 234-266.

Brown, M., Guin, B., \& Kirschenmann, K. (2016). Microfinance Banks and Financial Inclusion. Review of Finance, 20, 907-946. https://doi.org/10.1093/rof/rfv026

Burgess, R., Wong, G., \& Pande, R. (2005). Banking for the Poor : Evidence from India. Journal of the European Economic Association, 3, 268-278.

Carletti, E., Senbet, L. W., Cull, R., Allen, F., Qian, J. “QJ,” \& Valenzuela, P. (2018). Improving Access to Banking: Evidence from Kenya. The World Bank. https://doi.org/10.2139/ssrn.3305047

Demirgüç-Kunt, A., \& Klapper, L. (2013). Measuring Financial Inclusion: Explaining Variation in Use of Financial Services Across and within Countries. Brookings Papers on Economic Activity, SPRING 2013, 279-321. https://doi.org/10.1353/eca.2013.0002

Demirguc-Kunt, A., Klapper, L., Singer, D., Ansar, S., \& Hess, J. (2018). The Global Findex Database 2017: Measuring Financial Inclusion and the Fintech Revolution. The World Bank.

Dewan Nasional Keuangan Inklusif. (2019). Inklusi Keuangan Indonesia 2018. 
Diagne, A. (1999). Determinants of Household Access to and Participation in Formal and Informal Credit Markets in Malawi. International Food Policy Research Institute, 67, 1-62.

Ergungor, O. E. (2010). Bank Branch Presence and Access to Credit in Low-to Moderate-Income Neighborhoods. Journal of Money, Credit and Banking, 42, 1321-1349.

Esquivias, M. A., Sethi, N., Ramandha, M. D., \& Jayanti, A. D. (2020). Financial Inclusion Dynamics in Southeast Asia: An Empirical Investigation on Three Countries. Business Strategy and Development, August, 1-13. https://doi.org/10.1002/bsd2.139

Fitzpatrick, K. (2013). The Effect of Bank Account Ownership on Credit and Consumption: Evidence from the United Kingdom. Southern Economic Journal, 82, 131223135728009. https://doi.org/10.4284/0038-4038-2013.027

Fungáčová, Z., \& Weill, L. (2015). Understanding Financial Inclusion in China. China Economic Review, 34, 196-206. https://doi.org/10.1016/j.chieco.2014.12.004

G20 Financial Inclusion Expert Group. (2010). Innovative Financial Inclusion. Principles and Report on Innovative Financial Inclusion from the Access through Innovation Sub-Group of the G20 Financial Inclusion Experts Group. In Group. http://www.gpfi.org/sites/default/files/documents/Principles and Report on Innovative Financial Inclusion_0.pdf

Ghosh, S., \& Vinod, D. (2017). What Constrains Financial Inclusion for Women? Evidence from Indian Micro Data. World Development, 92, 60-81. https://doi.org/10.1016/j.worlddev.2016.11.011

Giné, X. (2011). Access to Capital in Rural Thailand: An Estimated Model of Formal vs. Informal Credit. Journal of Development Economics, 96, 16-29. https://doi.org/10.1016/j.jdeveco.2010.07.001

Gitaharie, B. Y., Soelistianingsih, L., \& Djutaharta, T. (2014). Financial Inclusion: Household Access to Credit in Indonesia. Competition and Cooperation in Economics and Business, IV, 309-319. https://doi.org/10.1201/9781315225227-35

Gujarati, D. N., \& Porter, D. C. (2004). Basic Econometrics (Statistic). In McGrawHill/Irwin (5th ed.). Douglas Reiner. https://doi.org/10.1126/science.1186874

Han, R., \& Melecky, M. (2013). Financial Inclusion for Stability: Access to Bank Deposits and the Deposit Growth during the Global Financial Crisis. Policy Research Working Paper, 6577. https://doi.org/10.1227/01.NEU.0000349921.14519.2A

Ho, S. Y., \& Iyke, B. N. (2018). Finance-growth-poverty Nexus: A Re-assessment of the Trickle-down Hypothesis in China. Economic Change and Restructuring, 51, 221-247.

Hogarth, J. M., \& O’Donnell, K. H. (1999). Banking Relationships of Lower-income Families and the Governmental Trend toward Electronic Payment. Federal Reserve Bulletin, 85, 459.

Hogarth, J. M., \& O'Donnell, K. H. (2000). If You Build it, will They Come? A Simulation of Financial Product Holdings among Low-to-moderate Income Households. Journal of Consumer Policy, 23, 409-444.

Honohan, P. (2008). Cross-country Variation in Household Access to Financial Services. Journal of Banking and Finance, 32, 2493-2500. https://doi.org/10.1016/j.jbankfin.2008.05.004 
Kabakova, O., \& Plaksenkov, E. (2018). Analysis of Factors Affecting Financial Inclusion: Ecosystem View. Journal of Business Research, 89, 198-205. https://doi.org/10.1016/j.jbusres.2018.01.066

Kochar, A. (2018). Branchless Banking: Evaluating the Doorstep Delivery of Financial Services in Rural India. Journal of Development Economics, 135, 160175. https://doi.org/10.1016/j.jdeveco.2018.07.001

Kumar, A., Pal, R., \& Pal, R. (2019). Usage of Formal Financial Services in India: Demand Barriers or Supply Constraints? Economic Modelling, 80, 244-259. https://doi.org/10.1016/j.econmod.2018.11.010

Li, L. (2018). Financial Inclusion and Poverty: The Role of Relative Income. China Economic Review, 52, 165-191. https://doi.org/10.1016/j.chieco.2018.07.006

Li, X., Gan, C., \& Hu, B. (2011). Accessibility to Microcredit by Chinese Rural Households. Journal of Asian Economics, 22, 235-246. https://doi.org/10.1016/j.asieco.2011.01.004

Mohieldin, M. S., \& Wright, P. W. (2000). Formal and Informal Credit Markets in Egypt. Economic Development and Cultural Change, 48, 656-670. https://doi.org/10.1086/452614

Mylonidis, N., Chletsos, M., \& Barbagianni, V. (2019). Financial Exclusion in the USA: Looking Beyond Demographics. Journal of Financial Stability, 40, 144-158. https://doi.org/10.1016/j.jfs.2017.09.004

Nuryakin, C., Sastiono, P., Maizar, F. A., Amin, P., Yunita, L., Puspita, N., Afrizal, M., \& Tjen, C. (2017). Financial Inclusion through Digital Financial Services and Branchless Banking: Inclusiveness, Challenges and Opportunities. LPEMFEBUI Working Paper, 008, 1-10.

Sahay, R., Čihák, M., Barajas, A., Mitra, S., Kyobe, A., Nian Mooi, Y., Reza Yousefi, S., Hassine, M., Holland, A., Ross, K., York, R., Mialou, A., Amidzic, G., Gutierrez, S., Costa Navajas, M., \& Yu, L. (2015). Financial Inclusion: Can it Meet Multiple Macroeconomic Goals? IMF Staff Discussion Note. https://www. imf.org/external/pubs/ft/sdn/2015/sdn1517.pdf

Sanjaya, I. M., \& Nursechafia. (2016). Inklusi Keuangan dan Pertumbuhan Inklusif : Analisis Antar Provinsi di Indonesia. Buletin Ekonomi Moneter Dan Perbankan, $18,281$.

Swamy, V. (2014). Financial Inclusion, Gender Dimension, and Economic Impact on Poor Households. World Development, 56, 1-15. https://doi.org/10.1016/j.worlddev.2013.10.019

Van Rooyen, C., Stewart, R., \& de Wet, T. (2012). The Impact of Microfinance in Sub-Saharan Africa: A Systematic Review of the Evidence. World Development, 40, 2249-2262. https://doi.org/10.1016/j.worlddev.2012.03.012 
APPENDIX

Table A

Multinomial Logit Regression Results with Java Variable

This table reports multinomial logit regresstion estimates. Result 1 without Java variable and Result 2 with Java variable. Standard errors are in parentheses ${ }^{*} \mathrm{p}<0.10,{ }^{* *} \mathrm{p}<0.05,{ }^{* * *} \mathrm{p}<0.01$. Source: The 2018 Susenas and 2018 Podes (processed with weighing)

\begin{tabular}{|c|c|c|}
\hline & Result 1 & Result 2 \\
\hline \multicolumn{3}{|l|}{ Informal Credit } \\
\hline \multicolumn{3}{|c|}{ Banked: Account Ownership in Bank / Cooperative } \\
\hline Account & $\begin{array}{c}-0.0994^{* * *} \\
(0.0316)\end{array}$ & $\begin{aligned}-0.0971^{* * *} \\
(0.0316) \\
\end{aligned}$ \\
\hline \multicolumn{3}{|c|}{ Availability: Existence / Availability of Financial Institutions } \\
\hline Bank & $\begin{array}{l}0.0554^{*} \\
(0.0308)\end{array}$ & $\begin{array}{l}0.0568^{*} \\
(0.0308)\end{array}$ \\
\hline BPR & $\begin{array}{l}-0.0263 \\
(0.0443)\end{array}$ & $\begin{array}{l}-0.0373 \\
(0.0443)\end{array}$ \\
\hline Cooperative & $\begin{array}{l}-0.00216 \\
(0.0314)\end{array}$ & $\begin{array}{l}-0.00966 \\
(0.0314)\end{array}$ \\
\hline $\begin{array}{l}\text { Control: Demographic and Social Economic } \\
\text { Characteristics (9) }\end{array}$ & $\checkmark$ & $\checkmark$ \\
\hline Control: Digital Access (2) & $\checkmark$ & $\checkmark$ \\
\hline Control: Asset Ownership (5) & $\checkmark$ & $\checkmark$ \\
\hline Java & & $\checkmark$ \\
\hline Constant & $\begin{array}{l}-4.494^{* * *} \\
(0.0808)\end{array}$ & $\begin{array}{l}-4.565^{* * *} \\
(0.0826)\end{array}$ \\
\hline \multicolumn{3}{|l|}{ Formal Credit } \\
\hline \multicolumn{3}{|c|}{ Banked: Account Ownership in Bank / Cooperative } \\
\hline Account & $\begin{array}{l}0.802^{* * *} \\
(0.0114)\end{array}$ & $\begin{array}{l}0.806^{* * *} \\
(0.0114)\end{array}$ \\
\hline \multicolumn{3}{|c|}{ Availability: Existence / Availability of Financial Institutions } \\
\hline Bank & $\begin{array}{c}0.0381^{* * *} \\
(0.0102)\end{array}$ & $\begin{array}{c}0.0459^{* * * *} \\
(0.0102)\end{array}$ \\
\hline BPR & $\begin{array}{c}0.0552^{* * *} \\
(0.0129)\end{array}$ & $\begin{array}{l}0.0285^{* *} \\
(0.0130)\end{array}$ \\
\hline Cooperative & $\begin{array}{c}0.177^{* * *} \\
(0.00994)\end{array}$ & $\begin{array}{l}0.158^{* * *} \\
(0.00997)\end{array}$ \\
\hline $\begin{array}{l}\text { Control: Demographic and Social Economic } \\
\text { Characteristics (9) }\end{array}$ & $\checkmark$ & $\checkmark$ \\
\hline Control: Digital Access (2) & $\checkmark$ & $\checkmark$ \\
\hline Control: Asset Ownership (5) & $\checkmark$ & $\checkmark$ \\
\hline Java & & $\checkmark$ \\
\hline Constant & $\begin{array}{l}-4.259^{* * *} \\
(0.0349)\end{array}$ & $\begin{array}{l}-4.431^{* * *} \\
(0.0355)\end{array}$ \\
\hline Observations & 294426 & 294426 \\
\hline Pseudo $R^{2}$ & 0.079 & 0.081 \\
\hline chi2 & 29160.7 & 30101.6 \\
\hline
\end{tabular}


This page is intentionally left blank 